\title{
Teacher Professional Development in Brazil: Colonization of Teachers' Voices
}

\author{
Daniele Nascimento \\ University of Alberta \\ danielad@ualberta.ca
}

\begin{abstract}
This paper focuses on professional development practices implemented in Brazil, and the influence of post-colonial views in the power-relation between the 'educational authorities' or 'experts' and teachers. The paper addresses how this relationship in professional development is mostly 'one-sided', as often it does not include the 'voices' of teachers. Rather, it prioritizes the assumptions many 'experts' have towards teachers' needs for growth, in which the choices of topics and the kind of professional development programs to be designed often follow an 'onefits-all' model or banking education as defined by Freire (1970). This paper emerged from the author's experience during her Master's thesis research (Nascimento, 2010). She addressed the challenges of teaching in public schools in Brazil, and its implications in a social justice context. Through the lens of different teachers who participated in a volunteer-based Canadian/Brazilian teacher professional development program, the research investigated in which ways the inclusion of teachers' voices in professional development programs could affect teachers' performance in a Brazilian context. During four years over the summer, Canadian teachers and Brazilian teachers worked together on a professional development program that aimed to encourage teachers to share their teaching experiences and reflect on their practice.
\end{abstract}

Keywords: professional development, teacher education, Brazil, voices, professional growth.

Cultural and Pedagogical Inquiry, 2014, 6(1), Special Issue, pp. 4-24

ISSN 1916-3460 (C) 2014 University of Alberta

http://ejournals.library.ualberta.ca/index.php/cpi/index 


\section{Introduction}

Being a teacher implies a wholeness connection of human relations. In other words, a teacher is formed by their own understanding of the world that influences their practice, and results in a sense of wholeness between the person and the professional. In order for education to bring forward authentic critical thinkers, teachers have to understand that "knowledge is never completed or finished, but must be persistently scrutinized, tested, and critically assessed for its validity in the now" (Smith, 2009, p.109).

In my Master's thesis research (Nascimento, 2010), I addressed the challenges of teaching in public schools in Brazil, and its implications in a social justice context. Through the lens of different teachers who participated in a volunteer-based Canadian/Brazilian teacher professional development program, the research investigated ways in which a low cost and ongoing teacher professional development program could affect teachers' performance. The volunteer PD program took place in Teresina, the capital of Piaui State in northeast region of Brazil. However, most teachers came from towns and rural areas within the Piaui State. Canadian teachers and Brazilian teachers worked together on a professional development program that aimed to encourage teachers to share their teaching experiences and reflect on their practice.

As the researcher insider/outsider, I found it challenging to disassociate myself from my own experience in my years teaching in Brazilian public schools. It was nice to revisit my old classroom with a new understanding of the meaning of being a teacher and the transformative role of education. The study relied on qualitative methods such as ethnography, observations, and free-flow interviews framed by critical theory to interpret the voices of teachers expressed through their experiences, their understanding of their own practices, and themselves in the context of education. In July 2009, my last year of the PD program, about sixteen out of the seventy-five Brazilian teachers who attended the professional development program for the past three years, participated in individual free flow tape-recorded interviews in which the researcher acted as a facilitator. During these interviews the participants brought some pictures that were meaningful to them as a memory tool to help them to reflect on their teaching journey. Some of the observations were done by the researcher during teaching workshops. The study found that the many surrounding factors that influence the effectiveness of teaching also seem to affect the 
identity of teachers (Nascimento, 2010).

The NewClassroom Project was a long-term volunteer based program run during the month of July from 2006 to 2009 in Teresina, Piaui State, Brazil. A region with visible socialeconomic inequality among social classes. Teaching, especially in public schools, being one of the least desirable professions due to poor teacher training and teaching support, among many other problems teachers have to overcome on daily-bases.

The program addressed the experiences of seventy-five grade five to twelve Brazilian teachers and eight Canadian-volunteer, mostly K-12 certified teachers from Calgary. The curriculum consisted of bringing forward the challenges, generating discussions and sharing problem-solving experiences of these teachers. In the morning Canadian teachers would facilitate classes on educational theory and classroom practices. In the afternoon Brazilian practitioners would facilitate educational workshops and teaching discussions. The program also included some cultural workshops where Brazilian and Canadian teachers learned about each others' regional-cultural aspects.

The majority of Brazilian teacher-participants pointed to the fact that in their experience, teacher professional development was scarce in their State, and the few provided were usually two-day in-service one-size-fits-all model which teachers were obliged to attend, taught by an "expert" hired by government authorities. Some teachers argued that these programs were meaningless for them as they had never been consulted on issues which were important for them to be addressed by these short-term programs.

A number of Brazilian teachers who attended the NewClassroom project confessed that this had been their first experience with teacher-focused professional development, and that they had never even considered that such type of professional development existed. A small minority of teachers, especially those who had to temporally relocate from small towns in order to attend the project in Teresina, said they had never attended teacher professional development of any kind.

During the four years of the project, one of the most discussed topics was the power relation in education. The challenging unbalanced relationship with those who make decisions on what teachers' need and experience. How teachers have to overcome a deficient teacher education, lack of democratic communication with administration as decisions were always imposed versus negotiated, and they go on mentioning other challenges such as low wages, 
precarious working conditions, lack of support from parents and the community in general because of the low teaching achievements coming out of public schools. Teachers felt desolated and worthless with their career. The majority of Brazilian teachers said they would change professions if they had a chance to pass another 'concurso' with a more promising career path (concurso is an entrance exam for public service). They also argued that depression was a common state of mind for teachers. The subject 'voice' was much present during the discussions as teachers found that expressing their thoughts helped them to gain their sense of value, ownership of their experiences as valid assets to guide and help others as well as themselves to face the complex and daunting profession.

While many Latin American countries have succeeded in providing access to basic education for great majority of children, education quality in the region remains very low. In an increasing globalised world where workers' skills and knowledge play an ever-important role countries with predominantly low-skilled workers are doomed stay behind, their citizen earning low wages and continuing to miss opportunities to escape poverty and enjoy a better life (Vegas \& Umansky, 2005, p. 1)

During the study, Brazilian teachers voiced their thoughts regarding important matters and the complexity of being a teacher. Here are some of the study interview transcriptions:

"Dinda" has been teaching about 25 years. She is nearing retirement, and was one of the most engaged student-teachers during these four years that the PD program took place. She mentioned that at the end her career, she felt tired and frustrated with her profession and that the project meant a personal achievement for her. She also said how she was strictly "'raditional," prioritizing a teachercentered approach that brought so many problems to her classroom. She had never experienced positive outcomes, and this affected her self-esteem and her health. She also told us she attended the project because it helped her to rethink her teaching practice, and made her to feel motivated to teach. In her own words she says that "slowly, I overcame the fear of interacting with my students, 
engaging them in teaching activities that I had learned during the project". The students seem to appreciate her work better and she felt each year her teaching had improved and she felt that as she ended her career she felt embraced with a sense of mission accomplished. (Nascimento, 2010, p. 43-44)

Another teacher who attended the study, "Seashore Man" is in his early forties and has been teaching for about 15 years. He works in two different cities, and struggles to handle the time intervals and the commute between the two cities by bus, in order to be able to keep the two jobs. He mentioned that 'time is scarce as well as money, and even though it was really hard to take the only time off in July to study in the project, it proved to be worth it'. He continues by saying that the project made him aware of new possibilities in teaching such as teaching did not have to be a stressful job if teachers could interact with their students and both, students and teachers could share responsibility for teaching and learning. Seashore Man also said: "teachers do not have to have all the answers or always be right".(Nascimento, 2010, p.44)

"Junior," who attended the PD program for four years, told us how he loved teaching and that the negative results in the public schools made him to feel frustrated and unmotivated. He confessed to have attended public schools, and be the first one in his family to achieve a university degree. He described his experience while taking his Teacher Education as a "tough road," trying to handle a full-time low pay job, and being a full-time student. He mentioned that he had a few good professors. However, he had a difficult time while attending university having to deal with some of the strict and under-trained professors who relied on authority and lack of respect to teach. Imposing seminar style classes where students would take all the responsibility of "teaching the class" without guidance or teaching materials, other than faded and out-of-date photocopy texts. He mentioned that some of his professors used to interrupt the presentations to make negative comments on students' potential and level of intelligence, embarrassing them in from their classmates when they made 
mistakes or lacked language skills during the seminary classes. As a consequence of this teaching behaviour many student-teachers would quit. (Nascimento, 2010, pp. 44- 45)

\section{Why Professional Development?}

A meaningful reflection on the experiences of teachers in their unique classroom contexts is necessary, in order to bridge the gap between educational theory and pedagogical practices. This emergent reflection of "teaching experience and theory" through professional development is vital to improve learning outcomes. As it might raise new possibilities and generate changes to teacher education, for both teachers already in the field of education, as well as for teachers being prepared by higher education institutions around the world. How can the inclusion of the “teachers' voices" in professional development influence the power-relation in education?

Teachers' views on growth and development point to the need of re-thinking of teaching practices through professional development. Glathorn (1995) suggests that teacher professional growth is a result of pedagogical experiences gained over time, and the re-examining of his or her teaching practices systematically. Villegas-Reimers (2003) explains that these formal experiences include "attending workshops, professional meetings, mentoring, etc" (p. 9). According to a TALIS (Teaching and Learning International Survey programme) report, 80 percent of teachers worldwide manifested a need for professional development. In countries such as Brazil, Ireland, Italy and Malaysia, one in seven teachers argues that in order to improve teaching outcomes, they highly need professional development, especially, when teaching in multicultural contexts (Burns \& Shadoian-Gersing, 2010). As the demand for professional development comes from the teachers, what is the importance of the "voice" of teachers in professional development? Villegas-Reimers (2003) explains that

The uniqueness of the individual setting will always be a critical factor in education. What works in one situation may not work in another...Because of the enormous variability in educational contexts, there will never be 'one right answer'. Instead there will be a collection of answers, each specific to a context. (p. 15)

Some studies suggest that the most effective teacher professional development approaches are the ones implemented on smaller scale. I also believe that an effective focus is on 
challenges attendee teachers' can relate to their practice, and that reflects the "strength of prior beliefs and cultural values as factors that may affect its results and impact" (Avalos, 2011, p. 14).

Assuming that the effectiveness of teaching can be directly related to the pedagogical growth of teachers, Hunt and Touzel (2009) argue that "reflective practitioners recognize and possess the skills, competencies and knowledge essential to effective practice and recognize that they must continually seek to further develop their abilities in order to achieve and maintain high levels of effectiveness" (pp. 6-7). The addition of teachers' educational perspectives is pivotal to developing more effective teacher professional development programs.

Rodriguez (2005) suggests that the role of a teacher is not only to teach but rather to be a facilitator who helps students to develop their own learning skills. Giroux's (1988) approach is to see "teachers as intellectuals;" he argues that teachers are active agents in the process of educating themselves and their students, which involves a progressive self-understanding and reflection of their own practice in order to critically respond to urgent contemporary issues, which challenges the educational field. This process is vital to better comply with changes, the 'knowledge and power' problematic, and diversity in classroom communities.

Teacher education is challenged to reflect on how to provide teachers with the pedagogical background to work with diversity. While in countries such as Canada multicultural perspectives has become an essential part of teacher education, due to the fact of teachers' being challenged to embrace a diverse range of students, not always having the time and/or the academic training to address the issues related to multiculturalism. In countries such as in Brazil, not as much multiculturalism but social-economic inequalities among students are a source of concerns for teachers as well as a precarious teacher preparation education.

Danielson (2006) points to three pre-requisites for teacher professional development to be used as a tool for teachers' growth: first, "an environment of respect," and I would add pedagogical meaningful support from school administration, meaning teachers' voices are included in the decision making process; secondly, "a vision of learning, and a culture of hard working"; and third, "opportunity" (Rodriguez, 2005). In other words, in order for teacher professional development to be effective it does not depend only on the teachers' willingness to change but rather a favourable educational environment for these changes to take places and which provides teachers with the support necessary for improving their practice. "For many years professional development has involved teachers attending conferences, taking part in 
seminar, workshops and short courses but not actually participating in course or program design" (Rodriguez, 2005, p. 6).

Traditional views of education might justify some of the professional development models in which teachers' voices are ignored, or represented by teaching specialists who deliver a "teacher course package" to fit all at once. For instance, the "in-service teacher professional development training, also known as the traditional approach, is a very popular choice of professional development model, especially in developing countries. This model, the way I understand it as a teacher, usually relies on educational government experts' knowledge to determine 'what and how' the program will be designed and implemented, usually with little or no active/reflective teacher input. The programs are mainly focused on lecture style short-term courses and/or workshops, and the themes chosen by the specialists are not always related to teaching 'situations' that teachers encounter in their classrooms on a daily basis. However, one of the advantages of this model is its reach, as it can be implemented to a larger number of teachers at once; even though, teaching outcomes might not be rewarding (Villegas-Reimers, 2003).

Limited understanding of teachers' practice, and its direct impact on the effectiveness of teacher professional development programs, often inform the so-called 'experts' who usually design these programs. This type of information has been used by many countries in order to articulate educational policies, skill/competencies statements, and methods included in standardized teachers' courses, which aim to address the challenges teachers face. Even though, these standardized programs might have good intent, and some progress has been achieved, they are still far from reaching their main goal, which is to provide educators with the tools for effective pedagogical growth. Standardized programs, such as 'one fits all model', might not be the best choice to promote tangible improvements in teaching outcomes, "Because they ignore the professional judgement of the teacher educator, and because they reduce the holistic nature of teaching to a technical/rational list of statements that are simple not adequate, valid nor reliable" (Rodriguez, 2005, p. 7). Rodriguez also argues that very little teacher competencies statements or development programs are developed in partnership with teachers; and when they are, very often, their perspectives are dismissed as "too simple" and are not given much credibility. What bring us to the matter of the value of teachers" "experience" and "knowledge" in the educational field from hiring to design of professional development programs; from curriculum to teaching 
practice? How can we assess experience? What are the parameters which establish the validity of experience?

My Brazilian experience as a teacher with teacher professional development during the eight years I taught was mostly represented by a scarce one-day "training" courses on a crowded classroom listening to a government expert about the things he/she thought I should learn. This fact might explain why in 2006 after been in Canada for a few years, I went back to Teresina, my hometown and where I had worked as a teacher for about eight years, to run a Canadian/Brazilian volunteer teacher development program which focus was on the teachers' voices, aiming to promote a pedagogical interchange of teaching experiences among teachers from different cultural backgrounds and contexts.

In the first year of the program as some volunteer Canadian teachers, mostly from Calgary Board of Education, and I introduced ourselves at the auditorium of the Universidade Estadual do Piaui (State University of Piaui) to the seventy-five local English teachers who would be attending the program. We were quite surprised with the general reaction of these teachers as we laid out the curriculum for the month-long professional development program. The PD program aimed to promote and facilitate pedagogical interaction among teachers as a mutual learning process, contrasting to 'Western' model of 'teaching teachers abroad', which is a very common professional development practice, especially among Western educational institutions. Our main goal was to exchange teaching experiences and develop relationships among teachers, in which we believed it would enrich pedagogical practices. However, I found a vacuum between our intentions and the reality of these Brazilian teachers concerning teacher education. I would never forget the look I got from most teachers during our first meeting, something I would describe as a 'suspicious look at a first sight'. Later, teachers attendees explained that teacher active participation in a professional development program was something new to them and it never been implemented in their previous PD experiences. It took Canadian Teachers and Brazilian teachers some time to get used to each other and develop trust. But I would insist that even after 4 years of the program, still small elements of colonial views were felt, on both sides, I believe due to language and cultural differences. For example, during the workshops where Canadian and Brazilian teachers had to plan and teach a class having each other as students. Brazilian teachers felt insecure at times because of language limitations and maybe the perspective of having "Western" teachers as audience. At the same time, some of the 
Canadian teachers seemed frustrated when they had to improvise because of the lack and/or the quality of educational resources available. For instance, when Canadian teachers tried to teach a class on how to open an e-mail account (as we found out that many Brazilian teachers, even though the government had provided them with Computer related courses, many of them did not know the basics of opening an e-mail account. Some teachers said they used to 'borrow' a friend's e-mail account when they needed to send an email) and then the Computer lab would not be working or internet connection would be so slow that we were not be able to finish the class within the time established.

\section{Teacher Research: Teachers' Voices and Colonialism}

The inclusion of teachers' voices and reflections on their own needs are important factors in the process of teachers' growth through professional development as they are the most informed agents about the daily workings of school. Many teacher professional development programs claims to be research based. In these cases, often, qualitative methods such as Case Studies and Ethnography, where teachers have a more active participation are not encouraged. The absence of teachers' voices limits the research outcomes, as they might exclude demanding educational concerns (Gitlin, Bringhurst, Burns, Cooley, Myers, Price, Russel, \& Tiess 1992).

Teacher professional development has become a vital factor on teaching performance. However, literature on professional development focusing on teachers' perspectives on professional growth is still scarce, especially in Latin America. According to Vegas and Umansky (2005) "two of the most commonly found observable factors related to student educational achievements in Latin America and studies of the determinant of students achievements in other developing countries are teacher education and training and teacher experience" (p. 31). Wilson and Berne (1999) argue that "professional teachers require professional development." The need for more studies on this field of education has been increasing. "Yet, what the field "knows" about teacher learning is rather puzzling. In part, this is due to the scattered and serendipitous nature of teachers' learning". The experience of beginning teachers after finishing their "formal" teacher education, and their encounter with classroom experience afterwards, "has the potential for teaching them lessons about what school is, what teachers do, and how people learn" (p. 173).

Conservative views represented in professional development programs are mainly due to 
the power-relation in the politics of education, where the "expert" is entirely responsible for decoding the challenges of classroom teachers. Giroux and McLaren (1989) argue that "the power of the conservative initiatives resides, in part, in its ability to link schooling to the ideology of the marketplace and to successfully champion the so-called virtues of Western civilization" (p. XIII). Knowledge and power offer an unbalanced perspective of equality in the process of learning and transforming not only "the word but the world" (Freire \& Macedo, 1987). Giroux (1988) suggests that

the material conditions under which teachers work constitute the basis for either delimitating or empowering their practice as intellectuals. Therefore, teachers as intellectuals will need to reconsider and, possibly, transform the fundamental nature of the conditions under which they work. ... They must create the ideology and structural condition necessary for them to write, research, and work with each other in producing curricula and sharing power. (p. XXXIV)

In my personal experience, when I finished my teaching degree, as with many new teachers, I quickly noticed the disassociation between the teacher education I received and the reality of the classroom practice. I was not prepared to deal with the challenges involving socialcultural diversity in the classroom. The curriculum was not meant to suit or represent equality in the diverse range of understandings of "knowledge." As an educator, I started reflecting on the debatable pedagogic issue around "knowledge," particularly the question of who defines which knowledge is most worthwhile. How is knowledge inserted in the curriculum and implemented for a wide range of students, often without pedagogical reflections on "who" is being privileged by this choice of knowledge? How does this knowledge reflect the influence of Euro-centric thinking in teachers' education, and its indoctrination towards the "global market" and power?

Freire (1970) argues that "teaching is a political act"; therefore, teachers' thinking cannot be a passive factor in the process of social-cultural transformation which education aims to accomplish. The power-relation in education does not offer too many opportunities to a meaningful understanding of how teachers' learn, as it seems to be one-sided where teachers' knowledge is often dismissed in the decision making process. Teachers are challenged to transcend their practice validation beyond the mainstream Euro-centric views of "knowledge," and its worthiness in educational settings. In some cases, this "colonial" approach of "one way of 
knowing," derived from "a unique knowledge," which prevents diverse cultural students to have their needs considered, and it might show a unilateral learning relationship with teachers.

\section{Over-representation of the "Western Model"}

A review of professional development literature worldwide done by Villegas-Reimers (2003) shows that there is an "over representation of cases, models and experiences in the US, Canada, Australia, and many other European countries, compared to that which I found in Asia, Africa, the Middle East and Latin America" (p. 7). Pinar (2004) argues that "having lost control of the curriculum public school teachers have been reduced to domestic workers instructed by positions, to clean up the 'mess' left by politics, culture and history" (p. XI).

In 2001, the United States started a promising new educational reform. The "No child left behind Act" developed and implemented a standardization educational testing model in the US public schools. It was an ambitious plan that, regardless of the amount of funding and quantitative research, failed to deliver the educational improvement/reform in the public school system aimed at by the US administration. Critiques point to the fact that there is no "magic formula" or "standard templates" to "fix education," especially if developed uniquely by the educational research "experts," excluding or giving little attention to teachers' voices towards what is important in educational (US Department of Education Website, 2012).

In Canada, economic stability and life style are some of the main reasons for many immigrants to choose Canada as their new home. In the past few decades, the demographics in the Canadian classrooms have been changing, and becoming more representative of the world. Teacher Professional Development has become an essential resource for teachers to connect with their culturally diverse classrooms. According to Guskey (1995), the uniqueness of the individual and their context are important factors to be considered in professional development programs. The school contexts are noticeably ethnically diverse and increasing numbers of immigrants have influenced and challenged teaching practices. My understanding is that a conversation and sharing of experiences among teachers from a diverse educational and social-cultural backgrounds helps to bridge the perception of the 'other', as the 'other' is also part of ourselves through similarities and differences.

In the worldview of traditionalists, schools are merely instructional sites. Public 
schooling offers limited individual mobility to members of the working class and other oppressed groups, but it is a powerful instrument for the reproductions of capitalist relations of production and the dominant legitimating ideologies of ruling groups. (Giroux, 1988, p. xxx)

Overall, I observed that there is limited literature or studies on teachers' understanding of "knowledge," "interests," and "professional priorities," in other words the needs and aspirations of a professional, educator, and a citizen. I also noticed that in countries such as Brazil teacher professional development programs are poorly founded on educational research, but often, inspired by Western educational models (World Bank, 2010). A number of teachers around the world, experience "a sense of muteness" as they are "trained" to be a "better teacher," and very often, their educational input is not considered in the decision making process of growth, which professional development programs claim to promote. In countries such as Canada, teachers can also feel overwhelmed by the many issues related to education such as the hegemony of a mainstream Euro-centric views on "knowledge and curriculum," "exclusive" multicultural polices, and social justice, among many other important and problematic social-educational issues which challenge our standpoints as educators. Despite all the problems, teachers in developed countries still share a fair amount of social respect, working conditions and compensation, freedom to make decisions in the classroom when compared to what teachers endure in developing countries.

The offspring of an educational critical reflection can have an impact on the politics of power-relation. In global times, rethinking "inclusion," specifically teacher inclusion which historically has been under-emphasized in relation to students' experiences in educational studies, has been difficult as it might challenge the established structures of Western education. In these difficult times, the role of education, especially "continuing" education represented by teacher professional development programs, is mainly to create a better and more engaging world. According to Dewey (1994) "as long as it (education) endures it struggles to use the surrounding energies in its own behalf" (Chapter 24). I believe that to educate is to have hope that the human element is still essential in the success of education as to transform and emancipate the society.

\section{The Brazilian Experience}


As a former Brazilian teacher, living for a decade in Canada, I have been reading recent literature on Brazilian education, and reflecting on my own experience while revisiting the teachers who participated in my study back in 2009. I felt that there is still a long road to go, a road full of "potholes" similar to the ones we notice as we drive through some of the Brazilian highways, especially, in the northeast region. The efforts made to improve the quality of education have only emphasized the old ideas of "oppression and power"; however, it also shows some signs of "resistance." I believe that as one the leading economies in the world, Brazil has "the global eyes" on them, which has helped to raise the social-cultural "standards," and required a review of social values of inclusion, not only internally but as part of a global community. Is it possible to change education when teachers are less important than the internationally tested methods or "formulas," they use to teach? Pinar (2009) defends a process of emancipation, or what he calls "independence" of teachers, in order to promote real social-economic changes. In the context of globalization, is education becoming another commodity built to "look good" but not to last so we can purchase a new product that promises to work better?

Some studies such as the ones presented by World Bank (2010) cite the changes and advances that Brazil has made towards improving their educational system. However, not much is mentioned in these same studies of the teachers' perspectives being included in these changes. Studies such as Mascarenhas-Iosef (2007), a University professor at the University Catholica in Brazil, gives a more clear picture of social-economic problems and the real challenges related to the power dynamic of education in Brazil, which has to deal with poverty, under-considered and educated teachers, and whole diversity of social, political and cultural discrepancy in the decision making process. Freire (1970) argues that "there is no neutrality in education," and its main goal should be to promote transformative emancipation, critical consciousness, and citizenship. In this process educator and pupils are the ones who together can promote the necessary changes in their reality.

The Brazilian educational system is influenced by the European educational model (World Bank, 2010). Huckle (2001) defines the European educational system as "the products of Enlightenment and modernity, designed to promote economic development, nationalism, and social cohesion". He continues to explain that "modernization has so far failed to deliver on its promises of equality, democracy and freedom, and schooling continues to reproduce unequal and 
exploitative social and environmental relations" (p.3).

In recent years, Brazil has emerged to economic growth, and its educational system has been under 'reform' aiming to improve teaching outcomes. However, these reforms have not bridged the social-educational gap and promoted equality and accessibility between the dominant classes and the subaltern (Schwartzman, 2003).

McLeod (2010) argues that post-colonial influences "continues to flourish today through representations, discourses, signs and images" (p. 35). The history of Education in Brazil is long rooted in colonialist views and oppression. These aspects are still, even if in a more subtle way, present in education today, regardless of the economical advances. Brazil still strives to tangle the internal social-economic disparity problems which splits the country, metaphorically, in a system of "social casts," resulting in inequality of educational opportunities (Schwartzman, 2003; Schwartzman \& Brock, 2005).

The highly theoretical in-service training delivered by many Brazilian universities contrasts dramatically with new trends in teacher professional development in OECD countries. There, training is increasingly focused on transmission of concrete, practical strategies and techniques distilled from observing highly effective teachers in action. (World Bank, 2010, p. 60)

Brazilian education differs in many aspects from most developed countries in its need to improve the quality of teacher education, salary compensation and work conditions, and the absence of democratic and critical approaches in professional development. Example of teaching practices or models used in countries such as Finland, or in other OECD countries, are used to inspire teachers in Brazil as a 'model to be followed' and 'implemented' in their classrooms. For instance, this 'model to be followed' is also exemplified in some of the teaching materials such as books which bring in its content a flirting relationship with colonial views in Western education. The main issue with these practices is the fact that teachers in OECD countries and teachers in Brazil, even though they have similarities in practice, have their own unique local classroom challenges in very different social-economic and cultural contexts. My question is to what extent can teachers use other social-economic and culturally different teachers' practice in their classroom experience? If so, why does it have to be a "one way" "learning from"? Would it be a different experience or more productive experience if there be a direct inter-relationship between 
teachers in Brazil and other parts of the world? How has post-colonial concepts of western superiority played a role in the power-relation in the educational system in Brazil? These questions are open to discussion in order to further understand teachers' growth and the role of professional development in a global context. I believe that a pedagogical dialogue among teachers coming from different cultural backgrounds and pedagogic education produce a reflection on "how and why" we do we do things the way we do. It also offers possibilities to reflect on our practice by taking into account different perspectives on teaching, in which could be adapted to guide similar challenges in our own education context.

The challenges are extreme, but a number of states are already working on comprehensive strategies. Some, such as Minas Gerais, are developing important new approaches to a key issue for secondary education: the balance between academic and vocational content. (World Bank, 2010, p. 10)

In terms of professional development programs, problems start during the decision making process, as they are mainly designed in the large "southern centers region" by "specialists," meaning higher-education professionals, and/by government staff. This fact becomes problematic in a country that is divided in five regions, which are very diverse social, economic and culturally. These centralized PD programs are implemented throughout the country in a one-fits-all model, often, missing local differentiating elements in which likely influences its outcomes. This process is also mostly characterized by the specialist who "speaks" and teachers who "listen." Foucault defined the power-relationship between "speaking and listening" as "prescribing and obeying" (Jones and Porter, 1998, p. 64). Can local teachers also be considered 'specialists' due to their unique experience in the classroom context and therefore, contribute to the elaboration of professional development programs?

Education spending is outpacing results. Brazil's current level of spending should be producing better results. The report cites government audits and research studies which have documented a serious degree of corruption and mismanagement of education funds and evidence that these are highly correlated with poor education quality and results. (Word Bank, 2010, p. 8) 
The same study above suggests that "raising teacher quality in Brazil will require recruiting higher-capacity individuals" (p. 8). These individuals usually come from the lower economic classes without many other choices of a career other than in teaching. I would argue that there are more factors involved to the way education in Brazil has been performing than "better choices" or "selection" of teachers; again, teachers are mostly blamed for the problems Brazilian public education faces.

While the report lauds the quantity of innovative programs, privately-supported initiatives, and substantial investments in new technologies being undertaken in Brazil, it points to an almost complete lack of cost effectiveness research to support policymakers' choices in these areas. (World Bank, 2010, p.8)

From a teacher stand-point, I think that the main concerns of teachers, when it comes to professional development programs, is how they can include their "voices," in other words "real needs," and how relevant the content of the program is to their teaching practice. In my experience, as a public school teacher in Brazil for almost 10 years ago, and in more recent years, through my Master's thesis study where I investigated the experiences of Brazilian teachers with professional development, I found a discrepancy between what the articles I read in which claim "great improvements" in Brazilian education, especially in the increase of professional development programs throughout the country, and what classroom teachers have to say about the efficiency of these programs. According to teachers, there is still a "feeling of hopelessness," about how they feel towards being a teacher, and how they are (mis)-represented through professional development programs, in which in their opinion, address neither their voices nor their needs.

Bhabha (1994) calls for the creation of an engaging space between different forces. Spivak (1995) asks “can the subaltern speak?" which translated into an educational context 'can the subaltern (teachers) speak? In order to promote a more democratic and efficient educational system, teachers and administration have to develop a relationship of mutual respect and responsibilities. Where both parts are committed to engage in the actions necessary to reach educational goals. In my opinion, as for now teachers and governmental administration do not have an "equal" relationship as teachers' expertise are underestimated/valued in decision making process, working together would be the first and most important step to implement an 
educational reform (p. 24).

The issues with "mis-representation" of the teachers' voices in the decision-making process, not only in educational polices but the choices of focus in professional development over-shadows the hopes for improvements and ways to overcome the colonial practices enforced on teachers. In other words, in order to overcome the status-quo of dominant postcolonial discourses in education, "we have sometimes to use ideas or tools which we know are problematic" (McLoud, 2010, p. 222).

In conclusion, I would argue that Brazilian education has taken the first steps towards changes, and the implementation of a more inclusive educational system. However, it is still lacking an open and democratic dialogue between those in power and teachers. I believe that reforms cannot be successfully implemented without the free and critical support and engagement of teachers' efforts. 


\section{References}

Avalos, B. (2011). Teacher professional development in Teaching and Teacher Education over ten years. Centre for Advanced Research in Education. Chile, Santiago. http://www.captura.uchile.cl/bitstream/handle/2250/14793/Avalos_Beatrice.pdf

Bhabha, H. (1994). The location of culture. New York, NY: Routledge.

Burns, T., \& Shadoian-Gersing, V. (2010). Educational research and innovation educating teachers for diversity: Meeting the challenge. OECD - Organization for Economic Cooperation \& Development Publishing.

Danielson, C. (2006). Teacher leadership that strengthens professional practice. Alexandria, VA: Association for Supervision and Curriculum Development.

Dewey, J. (1994). Democracy and education, chapter 24. ILT -Institute for Learning Technologies Digital Classics. Retrieved at March 19, 2013 from http://www.ilt.columbia.edu/publications/dewey.html

Freire, P. (1970). Pedagogy of the oppressed. New York, NW: Continuum.

Freire, P., \& Macedo, D. (1987). Literacy: Reading the word and the world. Westport, CT: Bergin \& Garvey.

Gitlin, A., Bringhurst, K., Burns, M., Cooley, V., Myers, B., Price, K., Russel, R., \& Tiess P. (1992). Teachers'voice for school change: An Introduction to Educative Research. London, UK: Rouledge.

Giroux, H. A. (1988). Teachers as intellectuals: Toward a critical pedagogy of learning. Westport, CT: Bergin \& Garvey Publishers.

Giroux, H. A., \& McLaren, P. (1989). Critical pedagogy, the state, and cultural struggle: Teacher empowerment and school reform. Albany, NY: State University of New York Press.

Glathorn, A. (1995). Teacher development. In L. W. Anderson (Ed.), International encyclopedia of teaching and teacher education ( $2^{\text {nd }}$ ed.). Tarrytown, NY: Elsevier Science Ltda.

Guskey, T. R. (1995). Professional development in education: In search of the optimal mix. In T. R. Guskey \& M. Huberman (Eds.), Professional development in education: New paradigms and practices. New York, NY: Teachers College Press.

Huckle, J. (2001). Education for sustainability and ecological citizenship in Europe: A challenge for teacher education in the 21st Century. Paper given at conference at the University of 
Thrace, Alexandroupolis, May 2001.

Hunt, H. G. \& Touzel, T. J. (2009). Effective teaching: Preparation and implementation. Springfield, IL: Charles C. Thomas Publisher.

Jones, C., \& Porter, R. (1998). Reassessing Foucault: Power, medicine and the body. New York, NY: Routledge.

Mascarenhas-iosef, R. (2007). A qualidade da educacao na escola publica e o comprometimento da cidadania global emancipada: Implicacao para a situacao de pobresa e desigualdade no Brazil. Retrieved March 5, 1012 from http://repositorio.bce.unb.br/bitstream/10482/2560/1/Tese_RanilceMascarenhasGIosif.pdf McLeod, J. (2010). Beginning postcolonialism (2 ${ }^{\text {nd }}$ Ed.). New York: NY, Manchester University Press.

Nascimento, D. (2010). Empowering teachers in the public system in Piaui State, Brazil through the Brazil/Canada NewClassroom Project for professional development. Thesis defended on September 7, 2010 at the University of Calgary in Calgary, AB.

Pinar, W. F. (2004). What is curriculum theory? Wahwah, NJ: Lawrence Erlbaum Associates Publishers, Inc.

Pinar, W. F. (2009). A declaration of independence. In W. F. Pinar (Ed.), The worldliness of a cosmopolitan education: Passionate lives in public service. New York: Routledge.

Rodriguez, S. (2005). International Perspectives On Teacher Professional Development: Changes Influenced by Politics, Pedagogy and Innovation. New York: Nova Science Publishers.

Schwartzman, S. (2003). Equity, quality and relevance in higher education in Brazil. Manuscript received on September 9, 2003; accepted for publication on October 28, 2003. Retrieved March 4, 2012 from http://www.scielo.br/pdf/aabc/v76n1/a15v76n1.pdf

Schwartzman, S., \& Brock C. (2005). Os desafios da educação no Brasil. Editora Nova Fronteira. Retrieved December 23, 2012 from http://www.schwartzman.org.br/simon/desafios/1desafios.pdf

Spivak, G. (1995). Can the subaltern speak? In B. Ashcroft, G. Griffiths \& H. Tiffin (Eds.), Postcolonial studies reader. New York, NY: Routledge.

Smith, D. G. (2009). Critical notice: Engaging Peter McLaren and the new Marxism in education. 
Interchange, 40(1), 93-117. doi: 10.1007/s10780-008-9082-z

TALIS (Teaching and Learning International Survey programme). Overview of Country Results In TALISS1: Brazil. Teachers' perceptions of their own effectiveness (self efficacy) and job satisfaction. Retrieved at April 6, 2012 from http://www.oecd.org/dataoecd/8/52/43071730.pdf

Vegas, E., \& Umansky, I. (2005). Improving teaching and learning through effective incentives. What can we learn from education reforms in Latin America? Washington, DC. The World Bank. Retrieved from https://openknowledge.worldbank.org/bitstream/handle/10986/8694 133266.pdf?sequence $=1$

US Department of Education Website (12/06/2010). Retrieved on December 10, 2012 from http://www2.ed.gov/policy/elsec/leg/esea02/index.html

Wilson, S. M., \& Berne, J. (1999). Teacher learning and the acquisition of professional knowledge: an examination of research on contemporary professional development. Review of Research in Education, 24, 173-209. American Educational Research Association. http://outlier.uchicago.edu/computerscience/OS4CS/landscapestudy/resources/Wison\%20an d\%20Berne,\%201999\%20(1).pdf

World Bank (December 21, 2010). Achieving world class education in Brazil: The Next Agenda. Human Development Sector Management Unit Latin America and the Caribbean Regional Office. Retrieved at April 3, 2012 from http://siteresources.worldbank.org/BRAZILINPOREXTN/Resources/38171661293020543041/FReport_Achieving_World_Class_Education_Brazil_Dec2010.pdf Villegas-Reimers, E. (2003). Teacher professional development: An international review on literature. Paris, FR: International Institute for Educational Planning Publisher. Retrieved at February 22, 2012 from http://unesdoc.unesco.org/images/0013/001330/133010e.pdf 